10-1996

\title{
Less-Than-Lethal Weapons and Police-Citizen Killings in U.S. Urban Areas
}

William C. Bailey

Cleveland State University, w.bailey@csuohio.edu

Follow this and additional works at: https://engagedscholarship.csuohio.edu/clsoc_crim_facpub

Part of the Criminology Commons, Place and Environment Commons, and the Social Control, Law, Crime, and Deviance Commons

How does access to this work benefit you? Let us know!

Publisher's Statement

(c) 1996 Sage Publications

\section{Original Citation}

Bailey, W. C. (1996). Less-Than-Lethal Weapons and Police-Citizen Killings in U.S. Urban Areas. Crime \& Delinquency, 42(4), 535-552. doi:10.1177/0011128796042004003

\section{Repository Citation}

Bailey, William C., "Less-Than-Lethal Weapons and Police-Citizen Killings in U.S. Urban Areas" (1996). Sociology \& Criminology Faculty Publications. 63.

https://engagedscholarship.csuohio.edu/clsoc_crim_facpub/63

This Article is brought to you for free and open access by the Sociology \& Criminology Department at EngagedScholarship@CSU. It has been accepted for inclusion in Sociology \& Criminology Faculty Publications by an authorized administrator of EngagedScholarship@CSU. For more information, please contact library.es@csuohio.edu. 


\title{
LESS-THAN-LETHAL WEAPONS AND POLICE-CITIZEN KILLINGS IN U.S. URBAN AREAS
}

\author{
William C. Bailey, Cleveland State University
}

This article was originally published in:

Bailey, William C. (1996). Less-than-Lethal Weapons and Police-Citizen Killings in U.S. Urban Areas. Crime and Delinquency, 42(4), 535-552.

Post-print standardized by MSL Academic Endeavors, the imprint of the Michael Schwartz Library at Cleveland State University, 2013

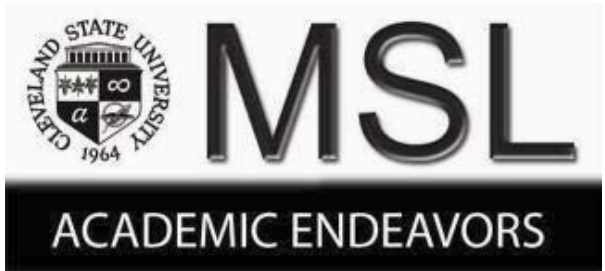




\title{
Less-than-Lethal Weapons and Police-Citizen Killings in U.S. Urban Areas
}

\author{
William C. Bailey
}

There appears to be general consensus in law enforcement circles that less-than-lethal weapons are effective in reducing police-citizen killings, but this "common wisdom" has not been subject to systematic empirical analysis. Considering a large sample of U.S. cities for 1990, this article examines the association between the availability to the police of various types of less-than-lethal weapons and general and race-specific justifiable homicide rates. The analysis produces no evidence that police killing rates are affected by the availability of less-than-lethal weapons.

There is long-standing consensus in law enforcement that in the United States homicide is a problem over which the police have little control (Federal Bureau of Investigation 1987). Citizen killings are due to a variety of societal and interpersonal forces such as urban blight, family deterioration, segregation, poverty, and income inequality, which are well beyond the control of the police. ${ }^{1}$

Although the police may be powerless to prevent citizens from killing one another, they are not helpless regarding the level at which officers are killed by citizens and police kill citizens in the line of duty. The FBI's Uniform Crime Reports (UCR) show that between 1980 and 1992, 1,000 law enforcement officers were killed in the line of duty. The highest number of killings occurred in 1980 (104) and the lowest in 1992 (62). In contrast, over this period the total number of assaults on law enforcement officers increased considerably $(57,847$ in $1980 ; 91,252$ in 1992), including those involving firearms $(3,295$ in 1980; 4,455 in 1992). The number of police officers killed per 1,000 total assaults and firearm assaults was much higher in 1980 (1.80 and 31.59, respectively) than in 1992 (.68 and 13.9). This significant decline in police killings is due in part to the role of technology. For example, a recent National Institute of Justice (NIJ) report points to developments in body

WILLIAM C. BAILEY: Professor, Sociology Department, Cleveland State University.

Address correspondence to William C. Bailey, Cleveland State University, Department of Sociology, Euclid Avenue at East 24th Street, Cleveland, OH 44115. 
armor as responsible for saving the lives of over 1,500 officers in recent years (NIJ 1994).

Technology also holds the promise of making the lives of citizens safer in police-citizen encounters; or, at least many police spokespersons are convinced that less-than-lethal weapons have the potential of considerably reducing the number of citizens who are killed by the police (Hayeslip and Preszler 1993; NIJ 1994; Stewart 1988; Sweetman 1987). Over the last 24 years, the NIJ sponsored two national conferences on the development and use of less-than-lethal weapons (Security Planning Corporation 1972; Sweetman 1987). In 1991 there was a small, high-level conference where selected academic and law enforcement leaders were assembled to chart the next round of NIJ research on less-than-lethal weapons (Nulton 1991). In addition, NIJ recently awarded a dozen grants totaling more than $\$ 2$ million to develop new less-than-lethal technologies (NIJ 1995a). This type of research remains an agency priority for 1995-1996 funding (NIJ 1995b).

It seems plausible that if law enforcement personnel are equipped properly with less-than-lethal weapons, a saving of citizen lives would occur. Lessthan-lethal weapons should be especially effective in (1) taking "difficult" suspects into custody, (2) responding to combatants with a weapon other than a firearm, (3) responding to many types of hostage situations, (4) transporting and managing difficult prisoners, and (5) responding to group disorders and riots.

Less-than-lethal weapons are not new in law enforcement. From the earliest days of organized policing, officers have been provided with various impact weapons (Peak 1990). In addition, police tactical units long have been equipped with devices such as tear gas, water cannons, and rubber bullets. The current interest is in making available hand-held, less-than-lethal devices to assist officers so that situations will not result in serious injury to suspects, or the police.

Without question, it would be desirable to equip police with less-thanlethal weapons that are effective, and to explore new devices that will make law enforcement less lethal. However, before making additional investments in existing devices and in new technologies, the question must be asked: How effective are the less-than-lethal weapons currently in use? For example, for well over a decade hand-held chemical and electrical devices have been used by police across the country. Is there any systematic evidence that the introduction of this technology has resulted in a decrease in the rate of police-citizen killings? The author's survey of the literature failed to identify any empirical study that assessed this question.

Neither have researchers examined the relationship between the availability of less-than-lethal weapons and police-citizen homicide rates crosssectionally for law enforcement agencies. The 1990 Law Enforcement Man- 
agement and Administrative Statistics survey (LEMAS) data show that impact weapons such as batons are authorized for use by $77 \%$ of municipal agencies, $78 \%$ of county sheriffs, and $65 \%$ of the state police (Bureau of Justice Statistics 1992). A somewhat smaller proportion of the three types of agencies authorize the use of less-than-lethal chemical agents $(70 \%, 69 \%$, and $61 \%$, respectively). Notably, only a minority of agencies authorize the use of electrical $(22 \%, 34 \%$ and $4 \%)$ and restraining devices $(20 \%, 26 \%$, and $25 \%$ ). Although informative, these figures do not reveal whether communities that equip police with one or more types of less-than-lethal weapons are successful in reducing police-citizen killings. For example, for the 380 municipal police departments involved in the 1990 LEMAS survey, were police killing rates lower in jurisdictions that authorized the use of chemical agents $(70 \%, n=266)$ compared with cities that did not $(30 \%, n=114)$ ? The same question can be raised about the other types of less-than-lethal devices.

In sum, based on the "common wisdom" of law enforcement authorities, it can be hypothesized that police-citizen killing rates should be lower for communities where officers are equipped with less-than-lethal weapons (Hayeslip and Preszler 1993; Sweetman 1987). Such killings should be lower yet in communities that authorize the use of a broad range of less-than-lethal devices. Despite this "common wisdom," it is unknown (1) whether lessthan-lethal weapons in general are more effective than traditional weapons (firearms) in reducing police-citizen killings, (2) which types of less-than-lethal weapons are more or less effective in reducing police-citizen killings (Sweetman 1987), and (3) which new technologies hold the greatest promise of reducing citizen killings (Nulton 1991). The research reported here is a step toward answering these questions.

\section{METHODOLOGY}

Drawing upon data for large U.S. cities for 1990, this study examines the relationship between (1) the availability of various types of less-than-lethal weapons and (2) rates of police-citizen killings for the public in general and for Whites and Blacks in particular. Bivariate and multivariate techniques are used to assess the effects of the availability of non-lethal devices on justifiable homicides by police.

\section{Jurisdictions}

To explore the effectiveness of less-than-lethal weapons, municipal law enforcement agencies serving U.S. cities with a 1990 population of at least 
100,000 persons are considered. The year 1990 is selected because of the availability of LEMAS data on less-than-lethal weapons. Also, since 1990 is a census year, sociodemographic data are available for control variable purposes. The analysis is restricted to municipal agencies that serve large communities because a disproportionate number of police-citizen killings occur in these cities. At the same time, the level of police-homicides varies considerably from one city to another.

\section{Police Killings: The Dependent Variable}

In principle, the task of developing an acceptable measure of police killing rates is quite manageable. However, operationally the available data pose various problems. Ideally, what is required for a sample of jurisdictions are accurate counts of justifiable homicides to serve as the numerator of the rate, and accurate counts of the number of police-citizen encounters where a citizen death is a possibility to serve as the denominator. Unfortunately, available data for forming both the numerator and denominator for police killing rates have important limitations.

\section{The Numerator: Police Killings}

There are two sources of national data on the number of citizens who die each year due to legal intervention, including police-citizen killings. First is the national death registry system of the National Center for Health Statistics (NCHS). The center maintains records furnished by medical examiners from across the United States for "deaths by legal intervention." These figures are published in the annual series, Vital Statistics of the United States. Unfortunately, NCHS figures are not adequate for the present study due to missing data. As Sherman and Langworthy (1979) note, U.S. Vital Statistics underreport justifiable homicides by as much as $50 \%$. To illustrate, NCHS figures for 1990 show a total of 297 deaths due to legal intervention, excluding 21 legal executions. In contrast, the FBI's Supplementary Homicide Reports for 1990 show a total of 458 justifiable homicides by police.

The Supplementary Homicide Reports (SHR) is the second source of national data on police-citizen killings. This is a voluntary nationwide program where individual law enforcement agencies or state-level coordinating authorities provide to the FBI data on victim, offender, and circumstance for cases of (1) murder and nonnegligent manslaughter, (2) manslaughter by negligence, and (3) justifiable homicide. The FBI defines police-involved justifiable homicide as "the killing of a [suspected] felon by a peace officer in the line of duty" $(1984$, p. 6$)$. For the purpose of this study, there are two 
problems with the SHR data. First, the FBI compiles only data for police killings involving suspected felons. Police-citizen killings resulting from lesser crimes that might also be considered "justifiable" are not available.

Second, there is a concern about the completeness of the SHR data. Almost all major law enforcement agencies participate in the SHR program. However, not all homicides that come to the attention of the police are reported. For example, for cities with a 1990 population of 100,000 or more, the 1990 UCR reports a total of 13,620 murders and nonnegligent manslaughters. For the same cities, the number of criminal homicides included in the SHR is 12,174 . This gap of 904 killings is not surprising. Homicide counts are much easier to compile for UCR reporting purposes than are the more detailed data called for by the SHR. Despite the gap between UCR and SHR figures, for large cities, the correlation between the SHR and UCR homicide counts is .986. This strong correspondence suggests that SHR figures for homicides (police or citizen) are reasonably representative across cities.

This view is supported by Sherman and Langworthy's (1979) detailed analysis of the strengths and weaknesses of various sources of justifiable homicide data, including those offered by the police and the NCHS. They conclude that although neither NCHS nor police data provide a totally accurate picture of justifiable homicides, police figures are preferable.

The present analysis relies upon SHR justifiable homicide data in computing police killing rates. For each city, an overall rate of justifiable homicide is computed, along with race-specific rates for White and Black citizens. There has been considerable debate in the literature about the "racial aspects" of police-citizen killings, including claims that the police have one trigger finger for Whites and quite another for Blacks (Takagi 1974). Race-specific rates are examined to determine if the suggested payoff of less-than-lethal weapons varies by race.

Previous research has shown that the number of police-citizen killings varies from year to year. To control for random fluctuations, the numerator in the rate measures is the 3-year (1989-1991) average number of policecitizen killings. Notably, the correlation between the 3-year mean and annual justifiable homicide counts is very high ( $r=.93$ to .97$)$. This suggests that random factors such as haphazard record keeping are not a serious concern with the SHR justifiable homicide data for the 1990 period.

\section{The Denominator Issue}

An ideal measure of police-citizen killings would have as its denominator the number of police-citizen encounters where a citizen death is a genuine possibility. Unfortunately, there are no data on the volume of potentially 
lethal police-citizen encounters. Faced with this problem, previous researchers have relied upon various proxy variables. The most common approach has been to standardize the number of citizens killed by the police by the number of citizens residing in the jurisdiction. Alternatively, some investigators have used arrest figures as the denominator in computing police killing rates. Here, rates are defined as the ratio of the number of citizens killed by the police to the number of citizens arrested by the police per 1,000 arrests. The rationale for arrest-based measures is that the level of arrests provides a reasonable indicator of the level of potentially lethal police-citizen encounters.

Both types of measures are employed here. First, police-citizen homicide victimization rates are computed as the number of total police-citizen killings per 100,000 total population. Rates for White and Black citizens also are computed per 100,000 White and Black persons, respectively. Second, arrest-based rates are formed for the total number of police-citizen killings per 100,000 citizen arrests. White and Black rates are computed per 100,000 White or Black citizen arrests. Unpublished city-level arrest figures were secured from the FBI.

\section{Less-than-Lethal-Weapons: The Independent Variable}

Police departments included in the 1990 LEMAS survey were asked to indicate if they authorized the use of (1) electrical, (2) chemical, (3) impact, (4) restraint, or (5) "other" types of less-than-lethal devices. Of the 187 municipal police departments serving a population of 100,000 or more, data were provided by 178 (95\%).jurisdictions. A majority of departments (77\%) authorized the use of less-than-lethal impact weapons. Fewer departments made available electrical $(28 \%)$, chemical $(71 \%)$, and restraining $(26 \%)$ devices. Only 13 departments $(6.6 \%)$ reported the use of other (unspecified) types of less-than-lethal weapons. (This unspecified category of weapons is not considered in this analysis.) In examining police-citizen killings, each type of less-than-lethal weapon is treated as a dummy variable: $1=$ yes, the type of weapon is available; $0=$ no, the weapon is not available to police in the jurisdiction. In addition, the analysis explores whether the availability of multiple types of weapons is associated with lower police killing rates.

\section{Control Variables}

Previous research suggests that the rate of police-citizen killing may be influenced by law enforcement and community-level variables. Relevant law enforcement factors include (1) the psychological screening of police appli- 
cants, (2) the amount of academy and field training required of recruits, (3) specific "shoot-don't shoot" training, and (4) human relations and cultural sensitivity training. At the community level, investigators have suggested that many of the sociodemographic factors that contribute to general homicides also influence the level of lethal assaults by the police against citizens (Sherman and Langworthy 1979).

To isolate the effect of less-than-lethal weapons, two law enforcement control variables are included in the analysis: the number of hours of academy training required of police recruits and the number of hours of field supervision required of academy graduates. For the cities under consideration, required class hours ranged from 40 to 1,400. Field supervision hours ranged from 0 to 4,160. Academy and field training data are drawn from the 1990 LEMAS survey.

The analysis does not include more direct measures of the impact of police training and procedures on police-citizen killings, such as whether departments have a written policy governing the use of deadly force, whether there is a required "shoot-don't shoot" training program, or the amount and type of less-than-lethal weapons training that a department requires. First, the LEMAS data show that virtually all large police departments have written policies governing the use of deadly force. Second, the LEMAS data do not indicate the type of firearm and less-than-lethal weapons training required of police.

Regarding community factors, studies spanning a number of years have reported that urban homicide rates are positively related to population size, percent Black population, percent poverty, the unemployment rate, the level of economic inequality, and the level of community disorganization as measured by the divorce rate. As noted, it has been speculated that such factors may also influence the level of lethal assaults by and against the police. Thus to better isolate the impact of less-than-lethal weapons on police killings, measures of these factors are included as control variables in multivariate analyses.

\section{Multicollinearity}

In multivariate analyses, there is always the risk that two or more predictor variables may be too highly associated to produce accurate (efficient) regression estimates for the collinear predictor(s). In this analysis, collinearity is not a problem for the variables of primary interest. Table 1 presents descriptive statistics and a correlation matrix for the less-than-lethal and control variables. The table shows very slight zero-order correlations among the different types of less-than-lethal weapons variables ( $r=0$ to .23 ). The zero-order correlations between the weapons and control variables are all also 
TABLE 1: Descriptive Statistics and Zero-Order Correlations Among Predictor and Control Variables

\begin{tabular}{|c|c|c|c|c|c|c|c|c|c|c|c|c|c|}
\hline Predictor Variables & 1 & 2 & 3 & 4 & 5 & 6 & 7 & 8 & 9 & 10 & 11 & 12 & 13 \\
\hline Population size (1000's) & 1.00 & & & & & & & & & & & & \\
\hline Black population (percentage) & .13 & 1.00 & & & & & & & & & & & \\
\hline Divorce rate & .03 & .37 & 1.00 & & & & & & & & & & \\
\hline Unemployment rate & .10 & .10 & .09 & 1.00 & & & & & & & & & \\
\hline Poverty (percentage) & .16 & .63 & .34 & .54 & 1.00 & & & & & & & & \\
\hline Income inequality & .25 & .52 & .35 & .13 & .65 & 1.00 & & & & & & & \\
\hline Number of class hours (100's) & .13 & -.03 & .04 & .09 & .11 & .15 & 1.00 & & & & & & \\
\hline Number of field hours (100's) & .05 & -.14 & .01 & .01 & -.04 & -.01 & -.03 & 1.00 & & & & & \\
\hline Impact weapons & -.05 & -.03 & .15 & -.05 & -.08 & -.06 & .03 & .06 & 1.00 & & & & \\
\hline Electrical devices & .16 & -.02 & .04 & -.04 & -.10 & -.06 & .08 & .08 & -.02 & 1.00 & & & \\
\hline Chemical agents & .12 & .04 & .07 & .12 & .08 & -.02 & .16 & -.02 & .01 & .23 & 1.00 & & \\
\hline Restraining devices & .03 & -.05 & .13 & -.09 & .04 & .10 & .05 & .05 & .00 & .21 & .11 & 1.00 & \\
\hline $\begin{array}{l}\text { Number of less-than-lethal } \\
\text { weapons available }\end{array}$ & .12 & -.03 & .17 & -.02 & -.02 & -.02 & .15 & .15 & .40 & .65 & .61 & .60 & 1.00 \\
\hline Mean & 336.40 & 19.20 & 13.20 & 6.80 & 12.30 & 39.30 & 6.30 & 5.80 & .81 & .29 & .74 & .27 & 2.11 \\
\hline$S D$ & 650.40 & 18.00 & 2.20 & 2.40 & 5.90 & 4.90 & 2.20 & 5.60 & .39 & .45 & .44 & .45 & .99 \\
\hline
\end{tabular}


very slight ( $r=-.02$ to .16$)$. Further, when each of the less-than-lethal weapon variables is regressed against all of the other predictors, the resulting multiple $R^{2}$ values are also very small (.035 to .085$)$.

\section{FINDINGS}

\section{Bivariate Results}

As noted, it is expected that communities where the police are authorized to use less-than-lethal weapons should have lower justifiable homicide rates. It is also hypothesized that citizen killings should be lower for communities where a greater variety of less-than-lethal weapons is available to the police.

Table 2 reports mean police killing rates for jurisdictions that vary in the provision for different types of less-than-lethal weapons. These figures do not support the above predictions. For no single type of less-than-lethal device are police killing rates consistently lower for cities that authorize the use of these alternative weapons. Similarly, for no single type of police killing are rates consistently lower for jurisdictions that provide for multiple types of less-than-lethal devices. Of the 24 "comparisons" in Table 2, police killing rates are lower for cities that provided for less-than-lethal weapons in only eight of $24(33 \%)$ instances. In none of the eight cases is the rate significantly lower (at the .05 level) for jurisdictions that equip police with less-than-lethal devices. Indeed, for total and White killings, rates based on population figures are significantly higher for cities that authorize the use of electrical devices.

Further, the data provide no indication that the availability of multiple types of less-than-lethal weapons is associated significantly with fewer police-citizen killings. One would expect a significant negative correlation between the number of available types of less-than-lethal weapons (a range of 0 to 4) and police killing rates, but this pattern does not hold for the jurisdictions and time period considered. The correlations are $.128, .176$, and .052 , respectively, for total killings per 100,000 population, White killings per 100,000 White population, and Black killings per 100,000 Black population. For rates based on arrests, the respective correlation coefficients are $.080, .041$, and .028 for total killings per 100,000 total arrests, White killings per 100,000 White arrests, and Black killings per 100,000 Black arrests.

\section{The Multivariate Analysis}

The question of whether law enforcement and sociodemographic factors condition or suppress the bivariate relationship between less-than-lethal 
TABLE 2: Mean Police-Citizen Killing Rates by the Availability of Types of Less-than-Lethal Weapons

\begin{tabular}{|c|c|c|c|c|c|c|c|c|}
\hline \multirow[b]{3}{*}{ Police Killing Rate } & \multicolumn{8}{|c|}{ Type of Less-than-Lethal Weapons Available } \\
\hline & \multicolumn{2}{|c|}{ Impact } & \multicolumn{2}{|c|}{ Electrical } & \multicolumn{2}{|c|}{ Chemical } & \multicolumn{2}{|c|}{ Restraining } \\
\hline & Yes & No & Yes & No & Yes & No & Yes & No \\
\hline Total killings per 100,000 total population & .280 & .231 & $.359^{\mathrm{a}}$ & 236 & .283 & .237 & .277 & .269 \\
\hline White killings per 100,000 White population & .245 & .203 & $.357^{\mathrm{b}}$ & $\cdot 189$ & .250 & .201 & .253 & .239 \\
\hline Black killings per 100,000 Black population & .449 & .204 & .459 & .381 & .398 & .418 & .366 & .417 \\
\hline Total killings per 100,000 total arrests & 3.890 & 3.601 & 4.918 & 3.402 & 4.025 & 3.304 & 3.555 & 3.941 \\
\hline White killings per 100,000 White arrests & 4.849 & 4.891 & 6.120 & 4.352 & 4.772 & 5.101 & 4.818 & 4.872 \\
\hline Black killings per 100,000 Black arrests & 3.692 & 2.141 & 3.953 & 3.182 & 3.373 & 3.495 & 2.826 & 3.627 \\
\hline Sample size & 141 & 32 & 50 & 123 & 129 & 46 & 48 & 127 \\
\hline
\end{tabular}

a. $p<.05$ 
weapons and police killings is explored in a series of multivariate analyses. The impact of each type of less-than-lethal weapon is examined for total citizen killings (Tables 3 and 4), killings of Whites (see Table 5), and killings of Blacks (see Table 6). In structuring the analysis, the sociodemographic and law enforcement variables are first considered, followed by the introduction, one at a time, of each type of less-than-lethal weapon. Finally, a summary variable indicating the total number of less-than-lethal weapons available to the police (a range of 0 to $4, \bar{x}=2.1$ ) is introduced.

\section{TOTAL POLICE KILLINGS}

Table 3 presents the analysis of rates of total police killings where the total population is the denominator. The results provide no indication that any of the four types of less-than-lethal weapons influence the rate of total policecitizen killings. The coefficients for the weapon variables are mixed in sign, slight in magnitude, and not statistically significant. In addition, in combination the less-than-lethal weapons do not significantly influence police killings rates.

Regarding non-weapon variables, the number of hours of police academy training is not associated significantly with rates, but the hours of required field supervision for rookie police officers is associated positively and significantly with police killings $(b=.009)$. The tradeoff is slight, but for reasons that are not clear, rates of citizen killings are higher for jurisdictions where police recruits receive more (not less) field supervision. Three of the sociodemographic variables also are associated positively and significantly with police killings: percent Black population, the divorce rate, and the employment rate. The tradeoffs are slight, but higher levels for each of these factors are associated with higher levels of police killings. Contrary to expectations, poverty has a significant negative association with rates for each type of police killing.

A similar pattern is apparent in Table 4 where police killing rates are based on total citizen arrests. The same sociodemographic factors are associated significantly with police killings. And again, there is a slight positive, but significant, association between rates and the number of hours of field supervision required of rookie officers.

Of central importance here is that the results provide no indication that less-than-lethal weapons reduce police-citizen killings. The availability of chemical agents and restraining devices is associated with lower rates, whereas the availability of impact weapons and electrical devices is associated with higher rates. However, in no case does the association reach statistical significance. Similarly, there is merely a chance association $(b=$ 
TABLE 3: Regression Results for Total Police Killings Based on the Size of the Total Population per 100,000

\begin{tabular}{|c|c|c|c|c|c|c|}
\hline Predictor Variables & $b$ & $b$ & $b$ & $b$ & $b$ & $b$ \\
\hline \multicolumn{7}{|l|}{ SES/Demographic factors } \\
\hline Population size & .000 & .000 & .000 & .000 & .000 & .000 \\
\hline Black population (percentage) & $.005^{a}$ & $.005^{a}$ & $.005^{\mathrm{a}}$ & $.005^{\mathrm{a}}$ & $.005^{\mathrm{a}}$ & $.005^{\mathrm{a}}$ \\
\hline Divorce rate & $.039^{\mathrm{a}}$ & $.038^{\mathrm{a}}$ & $.038^{\mathrm{a}}$ & $.039^{a}$ & $.039^{\mathrm{a}}$ & $.037^{\mathrm{a}}$ \\
\hline Unemployment rate & $.033^{\mathrm{a}}$ & $.033^{a}$ & $.033^{\mathrm{a}}$ & $.033^{\mathrm{a}}$ & $.033^{a}$ & $.034^{\mathrm{a}}$ \\
\hline Poverty (percentage) & $-.022^{a}$ & $-.012^{a}$ & $-.021^{a}$ & $-.022^{\mathrm{a}}$ & $-.022^{\mathrm{a}}$ & $-.022^{a}$ \\
\hline Income inequality & .011 & .011 & .011 & .011 & .011 & .012 \\
\hline \multicolumn{7}{|l|}{ Police training factors } \\
\hline Number of class hours (100's) & .000 & .01 & .01 & .01 & .014 & .012 \\
\hline Number of field hours ( 10 & $.009^{a}$ & $.009^{a}$ & $.009^{a}$ & $.009^{a}$ & $.009^{a}$ & $.009^{a}$ \\
\hline \multicolumn{7}{|l|}{ Less-than-lethal weapons } \\
\hline Impact weapons & - & .034 & - & - & - & - \\
\hline devices & - & - & .084 & - & - & - \\
\hline Chemical agents & - & - & - & .115 & - & - \\
\hline Restraining devices & - & - & - & - & .003 & - \\
\hline \multicolumn{7}{|l|}{ Number of less-than-lethal } \\
\hline weapons & - & - & - & - & - & .026 \\
\hline Constant & $-.894^{a}$ & $-.915^{\mathrm{a}}$ & $-.915^{\mathrm{a}}$ & $-.900^{\mathrm{a}}$ & $-.894^{a}$ & $-.931^{\mathrm{a}}$ \\
\hline$R^{2}$ value & $.193^{\mathrm{a}}$ & $.195^{\mathrm{a}}$ & $.204^{a}$ & $.193^{\mathrm{a}}$ & $.193^{\mathrm{a}}$ & $.300^{a}$ \\
\hline
\end{tabular}

a. $p<.05$

.202) between rates and the total number of available less-than-lethal weapons. Not unexpectedly, the respective coefficients for the less-than-lethal weapon variables are larger in Table 4 than in Table 3. Recall that police killing rates are higher (Table 1) when normed by the number of arrests compared with the size of the general population $(\overline{\mathrm{x}}=4.09$ versus $\overline{\mathrm{x}}=.28)$.

The goodness of fit of each of the models presented in Tables 3 and 4 also is rather poor $\left(R^{2}=.127\right.$ to .300$)$. One possible explanation is that police killing measures based on the total population are inadequate because they do not take into account the fact that not all groups are equally subject to being victims of justifiable homicide. For this sample of cities, the mean rates for the ratio of total persons killed by the police to total citizens, and to total arrests are .28 and 4.09 , respectively. However, for Whites the comparable figures are .25 and 5.19, and for Blacks they are .40 and 3.51. Thus for 1989-1991, Blacks experienced a $63 \%$ higher rate of police killings than would be expected based on their share of the total population. However, the average arrest-based police killing rate is $48 \%$ higher for Whites than for Blacks. In short, because of aggregation bias, overall police killing rates do not properly reflect the experience of either Whites or Blacks. The race-specific analyses that follow recognize and address this concern. 
TABLE 4: Regression Results for Total Police Killings Based on the Number of Total Persons Arrested per 100,000

\begin{tabular}{|c|c|c|c|c|c|c|}
\hline Predictor Variables & $b$ & $b$ & $b$ & $b$ & $b$ & $b$ \\
\hline \multicolumn{7}{|l|}{ SES/Demographic factors } \\
\hline Population size & .000 & .000 & .000 & .000 & .000 & .000 \\
\hline Black population (percentage) & .074 & $.074^{\mathrm{a}}$ & .071 & $.074^{\mathrm{a}}$ & $.072^{\mathrm{a}}$ & $.074^{\mathrm{a}}$ \\
\hline Divorce rate & $.386^{\mathrm{a}}$ & $.372^{\mathrm{a}}$ & $.369^{\mathrm{a}}$ & $.387^{a}$ & $.394^{\mathrm{a}}$ & $.367^{\mathrm{a}}$ \\
\hline Unemployment rate & $.345^{\mathrm{a}}$ & $.345^{\mathrm{a}}$ & $.341^{\mathrm{a}}$ & $.345^{\mathrm{a}}$ & $.337^{\mathrm{a}}$ & $.348^{\mathrm{a}}$ \\
\hline Poverty (percentage) & $-.259^{\mathrm{a}}$ & $-.258^{\mathrm{a}}$ & $-.245^{\mathrm{a}}$ & $-.259^{\mathrm{a}}$ & $-.255^{\mathrm{a}}$ & $-.260^{\mathrm{a}}$ \\
\hline Income inequality & -.012 & -.010 & -.005 & -.013 & -.011 & -.007 \\
\hline \multicolumn{7}{|l|}{ Police training factors } \\
\hline Number of class hours (100's) & .003 & 259 & 245 & .264 & .263 & 249 \\
\hline Number of field hours (100's) & $.200^{\mathrm{a}}$ & $.198^{\mathrm{a}}$ & $.193^{\mathrm{a}}$ & $.200^{\mathrm{a}}$ & $.200^{\mathrm{a}}$ & $.197^{\mathrm{a}}$ \\
\hline \multicolumn{7}{|l|}{ Less-than-lethal weapons } \\
\hline Impact weapons & - & .452 & - & - & - & - \\
\hline Electrical devices & - & - & .870 & - & - & - \\
\hline Chemical agents & - & - & - & -.030 & - & - \\
\hline Restraining devices & - & - & - & - & -.270 & - \\
\hline $\begin{array}{l}\text { Number of less-than-lethal } \\
\text { weapons }\end{array}$ & & - & - & - & - & .202 \\
\hline Constant & .559 & .825 & 4.773 & -4.534 & -4.625 & -4.844 \\
\hline$R^{2}$ value & $.127^{\mathrm{a}}$ & $.128^{\mathrm{a}}$ & $.133^{\mathrm{a}}$ & $.127^{\mathrm{a}}$ & $.128^{\mathrm{a}}$ & $.129^{\mathrm{a}}$ \\
\hline
\end{tabular}

a. $p<.05$

\section{POLICE KILLINGS OF WHITES}

The analysis of killings involving White citizens per 100,000 White population is reported in Table 5. As with total killings, the results provide no indication that rates of justifiable homicide involving Whites are associated significantly with the availability of impact, chemical, or restraining devices. However, contrary to expectations, there is a slight $(b=.140, p<$ $.05)$, but statistically significant, positive relationship between the availability of electrical weapons and White justifiable homicides. This pattern is consistent with the results reported in Table 2, which show that rates are significantly higher for jurisdictions that authorize $(\overline{\mathrm{x}}=.357)$ versus those that do not authorize $(\bar{x}=.189)$ the use of electrical devices. ${ }^{2}$

Also consistent with findings for total police killings, the divorce and unemployment rates are associated significantly and positively with White justifiable homicides for each model. Also like total killings, the overall goodness of fit for White killings is low $\left(R^{2}=.151\right.$ to .189$)$. Extending the analysis to consider rates based on the ratio of White police-citizen killings to White arrests does not alter the results. None of the less-than-lethal weapon variables is associated significantly with rates. Due to space constraints, these null findings are not presented in tabular form. 
TABLE 5: Regression Results for Police Killings of Whites Based on the Size of the White Population per 100,000

\begin{tabular}{|c|c|c|c|c|c|c|}
\hline Predictor Variables & $b$ & $b$ & $b$ & $b$ & $b$ & $b$ \\
\hline \multicolumn{7}{|l|}{ SES/Demographic factors } \\
\hline Population size & .000 & .000 & .000 & .000 & .000 & $: 000$ \\
\hline Black population (percentage) & -.002 & -.002 & -.002 & -.002 & -.002 & -.002 \\
\hline Divorce rate & $.039^{\mathrm{a}}$ & $.038^{\mathrm{a}}$ & $.036^{\mathrm{a}}$ & $.039^{\mathrm{a}}$ & $.039^{a}$ & $.036^{\mathrm{a}}$ \\
\hline Unemployment rate & $.034^{\mathrm{a}}$ & $.034^{\mathrm{a}}$ & $.033^{\mathrm{a}}$ & $.034^{\mathrm{a}}$ & $.034^{\mathrm{a}}$ & $.034^{a}$ \\
\hline Poverty (percentage) & -.012 & -.012 & -.010 & -.012 & -.012 & -.012 \\
\hline Income inequality & .007 & .007 & .008 & .007 & .007 & .008 \\
\hline \multicolumn{7}{|l|}{ Police training factors } \\
\hline Number of class hours (100's) & .000 & .014 & .011 & .014 & .014 & .012 \\
\hline Number of field hours (100's) & .000 & .005 & .004 & .005 & .005 & .004 \\
\hline \multicolumn{7}{|l|}{ Less-than-lethal weapons } \\
\hline Impact weapons & - & .030 & - & - & - & - \\
\hline Electrical devices & - & - & $.140^{\mathrm{a}}$ & - & - & - \\
\hline Chemical agents & - & - & - & -.003 & - & - \\
\hline Restraining devices & - & - & - & - & .000 & - \\
\hline \multicolumn{7}{|l|}{ Number of less-than-lethal } \\
\hline weapons & - & - & - & - & - & .035 \\
\hline Constant & -.749 & -.767 & $-.784^{\mathrm{a}}$ & $-.747^{\mathrm{a}}$ & -.749 & -.798 \\
\hline$R^{2}$ value & $.151^{\mathrm{a}}$ & $.153^{\mathrm{a}}$ & $.189^{\mathrm{a}}$ & $.151^{\mathrm{a}}$ & $.151^{a}$ & $.162^{\mathrm{a}}$ \\
\hline
\end{tabular}

a. $p<.05$

\section{POLICE KILLINGS OF BLACKS}

Table 6 reports the analysis where the dependent variable is the rate of police killings of Blacks per 100,000 Black population. Once again, the results provide no indication that less-than-lethal weapons influence justifiable homicides. There are negative but chance-only relationships between rates and the availability of chemical agents $(b=-.078)$ and restraining devices $(b=-.045)$. The relationships between rates and the availability of impact and electrical devices are positive but nonsignificant. The unemployment rate and level of income inequality are associated positively and significantly with justifiable homicide rates for Blacks; poverty has a significant negative impact on such killings. Finally, in combination, the predictor and control variables are also associated only slightly with Black police killing rates $\left(R^{2}=.128\right.$ to .142$)$.

The pattern of results does not change when rates based on the ratio of Black killings to Black arrests are considered. The coefficients for the less-than-lethal weapons variables, whether positive or negative, are very slight, and do not achieve statistical significance. 
TABLE 6: Regression Results for Police Killings of Blacks Based on the Size of the Black Population per 100,000

\begin{tabular}{|c|c|c|c|c|c|c|}
\hline Predictor Variables & $b$ & $b$ & $b$ & $b$ & $b$ & $b$ \\
\hline \multicolumn{7}{|l|}{ SES/Demographic factors } \\
\hline Population size & .000 & .000 & .000 & .000 & .000 & .000 \\
\hline Black population (percentage) & .007 & .007 & .007 & .007 & .007 & .007 \\
\hline Divorce rate & .034 & .027 & .034 & .035 & .035 & .032 \\
\hline Unemployment rate & $.081^{\mathrm{a}}$ & $.081^{a}$ & $.081^{\mathrm{a}}$ & $.082^{\mathrm{a}}$ & $.080^{\mathrm{a}}$ & $.082^{a}$ \\
\hline Poverty (percentage) & $-.039^{a}$ & $-.038^{a}$ & $-.039^{a}$ & $-.039^{a}$ & $-.038^{a}$ & $-.039^{a}$ \\
\hline Income inequality & $.031^{\mathrm{a}}$ & $.032^{\mathrm{a}}$ & $.031^{\mathrm{a}}$ & $.030^{\mathrm{a}}$ & $.031^{a}$ & $.031^{a}$ \\
\hline \multicolumn{7}{|l|}{ Police training factors } \\
\hline Number of class hours (100's) & .000 & .028 & .030 & .033 & .030 & .029 \\
\hline Number of field hours (100's) & .000 & .015 & .016 & .016 & .016 & .016 \\
\hline \multicolumn{7}{|l|}{ Less-than-lethal weapons } \\
\hline Impact weapons & - & .235 & - & - & - & - \\
\hline Electrical devices & - & - & .009 & - & - & - \\
\hline Chemical agents & - & - & - & -.078 & - & - \\
\hline Restraining devices & - & - & - & - & -.045 & - \\
\hline \multicolumn{7}{|l|}{ Number of less-than-lethal } \\
\hline weapons & - & - & - & - & - & .016 \\
\hline Constant & 1.798 & -1.936 & -1.800 & $-1.733^{a}$ & $1.809^{\mathrm{a}}$ & $-1.820^{a}$ \\
\hline$R^{2}$ value & $.128^{a}$ & $.142^{a}$ & $.128^{\mathrm{a}}$ & $.130^{\mathrm{a}}$ & $.129^{\mathrm{a}}$ & $.129^{a}$ \\
\hline
\end{tabular}

a. $p<.05$

\section{CONCLUSION}

The above analyses do not support the hypothesis that the availability of less-than-lethal weapons reduces rates of justifiable homicides in general, or for Blacks or Whites. To the contrary, the findings show overwhelmingly negligible results, thus suggesting that despite the high hopes of many law enforcement authorities, less-than-lethal weapons simply do not provide an improvement over "business as usual" in preventing police-citizen killings. Before drawing this conclusion, however, a few matters should be addressed.

\section{Adequacy of SHR Data}

First, how much confidence should be placed in the FBI data that have been used to compute justifiable homicide rates? Clearly, SHR data are flawed to some extent. However, it seems unlikely that the degree of bias is extreme enough to account for the null results reported above if, in fact, less-than-lethal weapons are effective in reducing police-citizen killings. It is hard to imagine a source of systematic bias in city-level SHR data that 
would reduce, to merely a chance level, the observed negative relationship between every type of less-than-lethal weapon and every measure of policecitizen killings.

\section{Adequacy of LEMAS Data}

It is also possible that the findings are due at least in part to the limitations of the LEMAS data. Police agencies were asked to respond (yes or no) to whether they made available impact, electrical, chemical, restraining or "other" less-than-lethal weapons. However, the responses to these questions do not inform us about the variety of different types of less-than-lethal weapons that fall within each of these broad categories. For example, it is possible that certain types of impact devices are very effective, but others are no more effective than firearms in preventing citizen deaths.

A yes response is also ambiguous in that it does not make clear whether all field personnel are equipped with particular types of less-than-lethal devices. Clearly, patrol officers are not regularly equipped with water cannons, flash bombs, and the like. However, it is not clear whether the majority of officers actually are equipped with the type of less-than-lethal weapons included in the 1990 LEMAS survey.

\section{Killings versus Police-Citizen Assaults}

Finally, the type of dependent variables examined may help to account for the negligible results. The analysis considered killings because of the promise of less-than-lethal weapons in reducing citizen deaths. However, whether a police-citizen confrontation results in a death depends on a number of factors beyond the availability of less-than-lethal weapons. Indeed, most often police use of a firearm does not result in a citizen being killed. With most firearm discharges, the police miss their mark; even when there is a hit, the person shot generally does not die.

These facts suggest that the number of persons shot at or wounded by the police, rather than simply police killings, might be important criterion variables for future study. Unfortunately, no systematic data are available for a reasonable cross-section of cities on weapon discharges by officers or the number of citizens who are shot at and wounded by the police. We urge future researchers to investigate the impact of less-than-lethal weapons on firearm discharges, citizen woundings, and killings by the police. Required figures could be gathered through a survey of police departments.

In sum, problems associated with the measures of police killing rates and less-than-lethal weapons could detract from properly identifying the relation- 
ship between the availability of less-than-lethal weapons and police-citizen killings. For this reason, it cannot be concluded from this investigation that less-than-lethal weapons are not capable of significantly reducing policecitizen killings. To draw such a conclusion requires alternative data to those used here. As noted, such data would most likely have to come from a survey of police departments. However, until such investigations are conducted, the persistent negative findings reported above cannot be ignored. For the 1990 period, police-citizen killing rates for large U.S. urban areas do not appear to have been responsive to the availability of less-than-lethal weapons.

\section{NOTES}

1. Conventionally, a nonlethal weapon is one that cannot cause death regardless of how it is used or applied. A less than-lethal-weapon is one designed to have a minimal probability of causing death, but it can result in death if used inappropriately or under unusual circumstances (Hayeslip and Preszler 1993).

2. One might speculate that the significant positive relationships between the availability of electrical devices and total and White-population-based police killing rates are a result of such weapons contributing to citizen deaths. This is doubtful. Some citizen deaths have resulted from the use of electrical devices, but such occurrences are rare (Sweetman 1987). Further, when rates for total and White victims are formed on the basis of citizen arrests as the denominator, electrical devices are not significantly associated with rates. Nor are rates of justifiable homicide for Blacks significantly associated with the availability of electrical devices (however normed). It might also be argued that a higher level of police killings might prompt a greater distribution and use of electrical weapons. This too is doubtful. Why, for example, would a higher level of such killings only produce an increased demand/distribution for electrical and not other types of less-than-lethal weapons? Also, why would such a demand be evident only for total and White justifiable homicide rates based on population size as the denominator? Why would such a demand not hold for Black justifiable homicides, however defined? In short, it simply is not clear why selected justifiable homicide rates are positively and significantly associated with the availability of less-than-lethal electrical devices.

\section{REFERENCES}

Bureau of Justice Statistics. 1992. Law Enforcement Management and Administrative Statistics, 1990. Washington DC: U.S. Government Printing Office.

Federal Bureau of Investigation. 1984. Uniform Crime Reporting Handbook. Washington DC: U.S. Government Printing Office.

1987. Crime in the United States, 1986. Washington, DC: U.S. Government Printing Office.

Hayeslip, David W. and Alan Preszler. 1993. Initiative on Less-than-Lethal Weapons. Washington, DC: U.S. Department of Justice, Office of Justice Programs, National Institute of Justice.

National Institute of Justice. 1994. 25 Years of Criminal Justice Research. Washington, DC: National Institute of Justice. 
1995a. NIJ Awards in Fiscal Year 1994. Washington, DC: National Institute of Justice. 1995b. NIJ Research Plans 1995-1996. Washington, DC: National Institute of Justice.

Nulton, David P. 1991. "Less than Lethal Force Focus Group Conference Confronts Technical Issues in Law Enforcement." The Law Officer 11:28.

Peak, Ken. 1990. "The Quest for Alternatives to Lethal Force: A Heuristic View." Journal of Contemporary Criminal Justice 6:8-22.

Security Planning Corporation. 1972. Non-Lethal Weapons for Law Enforcement. Washington, DC: Security Planning Corporation.

Sherman, Lawrence W. and Robert H. Langworthy. 1979. "Measuring Homicide by Police Officers." The Journal of Criminal Law and Criminology 70:546-60.

Stewart, James K. 1988. Remarks by the Honorable James Stewart to the Police Executive Research Forum. Annual Meeting, May 17, 1988. Washington, DC.

Sweetman, Sherri. 1987. Report on the Attorney General's Conference on Less than lethal Weapons. Washington, DC: U.S. Department of Justice, National Institute of Justice.

Takagi, Paul. 1974. "A Garrison State in a Democratic Society." Crime and Social Justice 85:27-33. 